\title{
Community participation in the Kampung KB Program in Jambi Province
}

\author{
Hardiani $^{1 *}$; Dwi Hastuti ${ }^{2}$; Hasriati Nasution ${ }^{3}$ \\ 1), 2) Faculty of Economics and Business, Universitas Jambi, Indonesia \\ ${ }^{3)}$ Faculty of Agriculture, Universitas Jambi, Indonesia \\ *To whom correspondence should be addressed.Email: hardiani@unja.ac.id

\begin{tabular}{|l|l|l|l|l|}
\hline DOI: & Received: & Revised: & Accepted: & Published: \\
10.22437/ppd.v9i4.11129 & 26.11 .2020 & 21.03 .2021 & 27.09 .2021 & 31.10 .2021 \\
\hline
\end{tabular}

\begin{abstract}
Kampung Keluarga Berkualitas (Kampung $K B$ ) is one of the development programs to create quality families in Indonesia. Kampung $K B$ is a village-level regional unit with integration and convergence in implementing empowerment and strengthening of family institutions in all its dimensions to improve the quality of human resources, families, and communities. The growth of Kampung KB in Jambi Province shows the high government's attention to this program to improve the quality of life of its people. However, the Kampung KB's success in improving the community's quality of life is largely determined by the level of community participation itself. This study analyzes the factors that influence community participation in the Kampung KB Program in Jambi Province. This study uses primary data obtained through target group respondents in Kampung $K B$ in Jambi Province. Data were analyzed using descriptive statistics and a binary logit regression model. The study results found that the overall level of community participation in the Kampung KB Program was moderate. The level of community participation was significantly related to education, length of stay at the location, and distance from house to the place of activity.
\end{abstract}

Keywords: Community participation, Kampung KB, Quality of life

JEL Classification: I15, I18, J13

\section{INTRODUCTION}

Kampung Keluarga Berencana (Kampung $K B$ ) is a National Population and Family Planning Board program or Badan Kependudukan dan Keluarga Berencana Nasional (BKKBN) which aims to improve the quality of life of the community at the citizenship association or Rukun Warga (RW), hamlet, or equivalent level through the Family Planning and Family Development Population program as well as other related sector development in realizing small families quality. In its implementation, the targets of this program are fertile age couples, older people, adolescents, families with children under five years of age (toddlers), families with teenagers, and families with elderly family members.

Indonesia has 14.536 Kampung $K B$ have been formed, which are spread across all provinces in Indonesia. This number has almost doubled compared to the initial conditions of the declaration 2016 of 7.449 Kampung KB (Ramadhan, 2019; BKKBN, 2019). This growth also occurred in Jambi Province from 53 Kampung $K B$ at the 
beginning to 202 Kampung $K B$ in 2019, which have spread across all districts/cities in Jambi Province. (Rahman, 2019; BKKBN, 2019).

The growth of Kampung $K B$ in Jambi Province shows the high government's attention to this program to improve the quality of life of its people. However, the Kampung KB's success in improving the community's quality of life is determined not only by the attention of the government, the synergy of the relevant ministries, working partners, and stakeholders but also largely determined by the level of community participation. Community participation, in this case, includes community participation from various target groups and at various stages, starting from planning activities, implementing, benefit to evaluating activities.

Although relatively limited, studies on the level of community participation in the village family planning program and the factors that influence it have been carried out in several regions in Indonesia. These studies include (Bintang, 2017) in Gianyar Regency; (Sarah \& Bukhari, 2018) in Banda Aceh; (Ali et al., 2019) in Mataram, (Muliawaty \& Maharto, 2019) in Cirebon and (Rahman \& Indrawadi, 2019) in Padang. However, a study regarding this matter has never been carried out in Jambi Province. Therefore, this research is important to do in Jambi Province to support the achievement of the Kampung $K B$ program to improve the quality of life of the people in this area.

In particular, this study aims to analyze community participation in the Kampung $K B$ Program in Jambi Province. Second, the factors influence community participation in the Kampung $K B$ Program in Jambi Province.

\section{LITERATURE REVIEW}

\section{Kampung KB}

Kampung $K B$ is an integrated development program and is integrated with various other development programs. The programs implemented in the Kampung $K B$ are oriented to population programs and are integrated, family planning, family development, and related sector development (BKKBN, 2015). This program was inaugurated on January 14, 2016, by the President of the Republic of Indonesia. The general objective of Kampung $K B$ is to improve the community's quality of life through population programs, family planning, family development, and related sector development in the context of realizing quality small families. The specific objectives are to increase the number of modern active family planning participants, increase family resilience through the Toddler Family Development program, Youth Family Development, Elderly Family Development, and the Youth Counseling Information Center, and raise awareness community about insightful development (BKKBN, 2015).

The target groups of the Kampung KB are: (1) family, (2), teenagers, (3) older people, (4) fertile age couples, (5) families with toddlers, (6) families with teenagers, (7) elderly families, and (7) sector targets according to their respective fields of work. The executor-related sector field officers, village/sub-district level Family Welfare Development, rural community institutions (PPKBD and Sub PPKBD), community leaders (traditional leaders/figures religion in the village), and cadres.

\section{Community participation}

Community participation is defined as the willingness to contribute, involvement, and community support both directly and indirectly in government programs (Tampi et al., 2020; Rofiq, 2018; Afiat et al., 2018; Sumaryadi, 2005). Cohen \& Uphoff (1980) divide community participation into four stages, namely: (1) participation in decisionmaking; (2) participation in implementation; (3) participation in benefits; and (4) participation in evaluation. 
On the other hand, in the context of the level of participation, Arnstein (1969) in (Nanda et al., 2018) divides it into eight levels, namely: First, manipulation where people are only gathered to ask for approval (signatures) without discussing the plan that should be discussed. In other words, at this level, there is a manipulative agenda. Second, therapy, where the community is asked to explain the problem, but the government does not solve the problem as promised. Third, to inform where there is only one-way communication from the government to the community at this level. Fourth is a consultation where the community has been allowed to earn income at this level, but there is no guarantee that this opinion is taken into account. Fifth, it is reassuring that the poor are already involved in an activity, but the legitimacy and appropriateness of advice remain with the power holders. Seventh, power is delegated, where the community has dominated decision-making at this level. Finally, citizen control, where the activities are fully controlled by the community at this level. Furthermore, of the eight levels, according to Arnstein (1969) (Nanda et al., 2018), it can be divided into three groups of levels, namely non-participation (manipulation and therapy), tokenism (informing, consultation, and placation), and citizen power (partnership, delegated power, and citizen control).

\section{Factors affecting community participation}

Community participation in the Kampung $K B$ program is community participation in various activities in the Kampung $K B$, such as attending child development consultations, participating in Tapos (Taman Posyandu), participating in elderly health consultations, participating in elderly gymnastics, following socialization on family planning, participating in contraceptive use activities all of which are included in the activities of Bina Keluarga Balita (BKB), Bina Keluarga Lansia (BKL), and family planning safaris.

Previous research has shown the low level of community participation in the Kampung KB program (Rizal \& Yulini, 2016; Bintang, 2017; Rahman \& Indrawadi, 2019; Ali et al., 2019; Muliawaty \& Maharto, 2019). Various factors influence community participation, both internal factors from within the individual and external factors that affect individual behavior.

This research is focused on internal factors that influence community participation. Research (Sarah \& Bukhari, 2018) in Banda Aceh found that gender, occupation, education, and length of stay affected community participation in Kampung $K B$. Research (Suroso et al., 2014) related to development planning in Gresik Regency shows that age, education level, and type of work have a significant relationship with the level of community participation. Wijayanti's research (2011) related to the level of community participation in the Telaga Village CSR program found that the level of income and the number of family burdens did not significantly affect

A person's spare time to be involved in organizations or activities in the community is also influenced by the type of work. Many busy residents with their main work or daily activities are less interested in attending meetings, discussions, or seminars (Budiharjo \& Sujarto, 2009). The results of other studies show that internal factors, including willingness in the form of attitudes and motivation and abilities in the form of knowledge, skills, and experiences possessed by individuals, have a significant influence on community participation (Lokita, 2011; Mardikanto \& Soebiato, 2013).

\section{METHODS}

This research used primary data collected from respondents in the target group of Kampung $K B$ in Jambi Province. The population in this study were all target groups of 
Kampung $K B$ in Jambi Province consisting of Fertile Age Couples, older people, adolescents, families with children under five years of age (toddlers), families with adolescents, and families with elderly family members.

Sampling using the stratified two-stage sampling method, namely: The first stage, selecting two samples of Kampung $K B$. The selection was carried out by purposive sampling, namely by selecting one family planning village with a low level of community participation and one family planning village with a high level of community participation. The determination of the Kampung KB was discussed with the BKKBN as the agency responsible for the main activities. Based on this, Mengupeh Village, Tengah Ilir District, Tebo Regency and Lingkar Selatan Village, Paal Merah District, Jambi City were designated as research locations. The second stage, selecting a sample of 5 percent of the target population at the research location. Sampling was done by stratified random sampling based on the target group in the Kampung $K B$.

Based on this, the number of samples according to the research location and the target group is given in Table 1 .

Table 1. Distribution of Kampung KB respondents by type of program participated/targeted in Jambi Province in 2020

\begin{tabular}{lcc}
\hline \multirow{2}{*}{ Target Group } & \multicolumn{2}{c}{ Location } \\
\cline { 2 - 3 } & Mengupeh Village & Paal Merah Sub-District \\
\hline Fertile age couple & 10 & 21 \\
Elderly people & 5 & 2 \\
Teenagers & 11 & 10 \\
Toddler Family Development & 6 & 15 \\
Elderly Family Development & 5 & 15 \\
Youth Family Development & 5 & 12 \\
UPPKS & 8 & 9 \\
\hline Total & 50 & 84 \\
\hline
\end{tabular}

Data collection instruments using a questionnaire. Through a questionnaire, community participation was measured from the decision-making stage to the evaluation of activity results. The number of activities involves the respondent's participation in planning Kampung $K B$ activities. Community involvement is assessed by attendance at planning meetings, activeness in meetings, and decision-making control. Respondents' answers are measured using a Likert scale of 1 - 5. The accumulated value of the Likert scale is used as the value of the respondent's level of participation. Data were analyzed using descriptive statistics.

Furthermore, to analyze the factors that influence the level of community participation in $\mathrm{KB}$ village activities/programs using a binary logit regression model with the following equation:

$$
\begin{aligned}
Y=\beta_{0}+\beta_{1 D 1} & X_{1 D 1}+\beta_{1 D 2} X_{1 D 2}+\beta_{2} X_{2}+\beta_{3 D 1} X_{3 D 1}+\beta_{3 D 2} X_{3 D 2}+\beta_{4 D 1} X_{4 D 1} \\
& +\beta_{4 D 2} X_{4 D 2}+\beta_{5 D 1} X_{5 D 1}+\beta_{5 D 2} X_{5 D 2}+\beta_{6 D 1} X_{6 D 1}+\beta_{6 D 2} X_{6 D 2}+e i
\end{aligned}
$$

$\mathrm{Y}=$ Participation rate, where $0=$ low, $1=$ medium $/$ high

$\mathrm{X} 1=$ Age, with basic category $=<24$ years old

X1D1 $1=$ if age $25-44$ years, $0=$ Others

$\mathrm{X} 1 \mathrm{D} 21=$ if age $>=45$ years, $0=$ Others

$\mathrm{X} 2=$ Gender, as a dummy variable with criteria $1=$ Male, $0=$ Female

$\mathrm{X} 3=$ Formal education with basic category elementary school

X3D1 1 = If junior high school, $0=$ Others

X3D2 $1=$ If high school and university, $0=$ Others 
$\mathrm{X} 4$ = Main activity with basic category of work

X4D1 $1=$ If it's a housekeepers, $0=$ Others

X4D2 1 = If school/other, $0=$ Other

$\mathrm{X} 5$ = Length of stay, with the basic category "new" (less than 2 years)

$\mathrm{X} 5 \mathrm{D} 1=$ medium $(2-4$ years $)$

$\mathrm{X} 5 \mathrm{D} 2=$ old (more than 4 years)

X6 $=$ Distance from house to the place of activity, with the basic category "close"

distance

$\mathrm{X} 6 \mathrm{D} 1=$ medium distance

$\mathrm{X} 6 \mathrm{D} 2$ = long distance

The distance from the house to the place of activity is measured in meters. Considering that the research areas have different characteristics, the grouping is also divided into:

For Mengupeh Village, Tengah Ilir District, Tebo Regency

- Close category, if the distance from the house to the place of activity is less than 1000 meters

- Medium category, if the distance from the house to the place of activity is between 1000 meters to 2000 meters

- Remote category, if the distance from the house to the place of activity is more than 2000 meters

For South Lingkar Village, Paal Merah District, Jambi City

- Close category, if the distance from the house to the place of activity is less than 200 meters

- Medium category, if the distance from the house to the place of activity is between 200 meters to 400 meters

- Remote category, if the distance from the house to the place of activity is more than 400 meters

\section{RESULTS AND DISCUSSIONS}

\section{Level of community participation in the Kampung KB Program}

Overall, community participation in the Kampung $K B$ Program is medium (average score is 2-3). Based on the stages, community participation in the decisionmaking and evaluation stage is low (average score is below 2). At the implementation stage, it is in the medium category, and at the stage of benefit-participation is highcategory (average score is above 3 ).

The low level of community participation in development programs, especially decision-making, aligns with research by Lutpi (2016) and Herman (2019). However, the results of this study differ from the findings of Saepudin et al. (2018) and Widodo (2018), which show high community participation in the planning stage. It should be understood that the activeness of the community in conveying ideas or ideas in the planning stage reflects that the community has understood and understood the problems or constraints of development.

Furthermore, the low community participation in development programs, especially at the evaluation stage, aligns with Wahyuni \& Manaf's (2016) research. However, the findings of this study are different from the research findings of Saepudin et al. (2018). 
Table 2. Community participation in the Kampung KB Program based on participation stages

\begin{tabular}{|c|c|c|c|c|}
\hline Stages & Frequency & Percent & Average & Category \\
\hline \multicolumn{5}{|l|}{ Decision making } \\
\hline Low & 71 & 52.99 & \multirow{3}{*}{1.88} & \multirow{3}{*}{ Low } \\
\hline Moderate & 59 & 44.03 & & \\
\hline High & 4 & 2.99 & & \\
\hline \multicolumn{5}{|l|}{ Implementation } \\
\hline Low & 44 & 32.84 & \multirow{3}{*}{2.20} & \multirow{3}{*}{ Moderate } \\
\hline Moderate & 77 & 57.46 & & \\
\hline High & 13 & 9.70 & & \\
\hline \multicolumn{5}{|l|}{ Benefit } \\
\hline Moderate & 101 & 75.37 & \multirow{2}{*}{3.02} & \multirow{2}{*}{ High } \\
\hline High & 33 & 24.63 & & \\
\hline \multicolumn{5}{|l|}{ Evaluation } \\
\hline Low & 85 & 63.43 & \multirow{3}{*}{1.84} & \multirow{3}{*}{ Low } \\
\hline Moderate & 41 & 30.60 & & \\
\hline High & 8 & 5.97 & & \\
\hline \multicolumn{5}{|c|}{ Total Participation } \\
\hline Low & 43 & 32.1 & \multirow{3}{*}{2.24} & \multirow{3}{*}{ Moderate } \\
\hline Moderate & 86 & 64.2 & & \\
\hline High & 5 & 3.7 & & \\
\hline
\end{tabular}

Determinants of the level of community participation in the Kampung KB Program in Jambi Province

\section{Overall model fit test}

Overall Model Fit Test is given in Table 3. Based on the Omnibus Test of Model Coefficients, the Chi_Square statistical value is 25,733 with a significance probability $(p)=0.007$. Thus, it can be concluded that the independent variables in the model jointly affect the level of community participation in KB village activities/programs. Based on the Hosmer and Lemeshow test, the Chi-Square value was 7.489 with a pvalue of 0.485 . Because Chi_Square is not significant ( $p>0.05$ ), it can be concluded that the predicted probability corresponds to the observed probability. In other words, there is no difference between the model and the data, so that the model can be said to be fit.

Table 3. Overall model fit test for community participation model

\begin{tabular}{lrrr}
\hline & Chi-square & df & Sig. \\
\hline Omnibus Test of Model Coefficients & 25,733 & 11 &, 007 \\
Hosmer and Lemeshow Test & 7,489 & 8 &, 485 \\
\hline
\end{tabular}

Furthermore, the $2 \times 2$ classification table (Table 4) shows how well the model classifies cases into two groups, both low and medium/high participation levels. The overall prediction accuracy is 72.4 percent, while the prediction accuracy for the low participation rate is 34.9 percent, and the medium/high participation rate is 90.1 percent. In other words, the accuracy of this model in predicting the probability of moderate/high participation rates is relatively greater than that of low participation rates. 
Table 4. Classification table for community participation model

\begin{tabular}{|c|c|c|c|c|}
\hline \multirow{3}{*}{ Observed } & & \multicolumn{3}{|c|}{ Predicted } \\
\hline & & \multicolumn{2}{|c|}{ Category } & \multirow{2}{*}{$\begin{array}{c}\text { Percentage } \\
\text { correct }\end{array}$} \\
\hline & & Low & Medium/High & \\
\hline \multirow[t]{2}{*}{ Category } & Low & 15 & 28 & 34,9 \\
\hline & Medium/High & 9 & 82 & 90,1 \\
\hline Overal per & entage & & & 72.4 \\
\hline
\end{tabular}

\section{Model coefficient estimation and partial hypothesis testing}

The model coefficients' estimation and the model's partial hypothesis testing are given in Table 5. Based on Table 5. shows that of the six variables in the model, three variables, namely age, gender, and main activity, have no significant effect on the level of community participation in the Kampung $K B$ program. This means no difference in community participation between age groups, gender, or main activities.

There is no effect of age on the level of participation, in line with the findings of Septiandari et al. (2015), Ristiana et al. (2020). However, the results of this study are different from those of Suroso et al. (2014) and Wahyuni \& Manaf (2016). There is no effect of gender on the level of participation in line with the research findings of Septiandari et al. (2015) and Ristiana et al. (2020). Furthermore, the main activity (type of work) on participation differs from the research findings of Suroso et al. (2014).

Regarding education, it can be seen that both X3_D1 (junior high school education) and X3_D2 (high school education and above) variables show a significant effect. It means that there is a difference in the level of participation between those with junior high school education and lower high school education and those with elementary school education and below (as the basic category).

The influence of education on the level of participation is in line with the research of Septiandari et al. (2015), Alhafidh \& Sunaryo (2015), and Suroso et al. (2014). However, the results of this study are different from the research findings of Ristiana et al. (2020) and Wahyuni \& Manaf (2016).

The odds ratio value shows that those with a junior high school education have a 3,454 times (higher) probability of actively participating (medium/high category participation) than those with elementary school education and below. Furthermore, the odds ratio value shows that those with high school education and above have a 3,202 times (higher) probability of actively participating (medium/high category participation) than those with elementary school education and below.

Only the variable X5_D1 (long stay in the medium category) has a significant effect on the length of stay. In contrast, the variable X5_D2 (the length of stay in the old category) has no significant effect. This shows a difference in the length of stay in the medium category to the length of stay in the new category. On the other hand, there is no difference in the duration of living in the "old" category with the length of stay in the new category. The non-effect of the length of stay is different from the research findings of Suroso et al. (2014) and Ristiana et al. (2020).

Based on the odds ratio, it shows that those who live in the medium category have a 2.858 times (higher) probability of actively participating (medium/high category participation) than those who are new to living in the area (as the base category).

Furthermore, related to the distance of the house from the place of activity, it shows that the variables X6_D1 (medium distance) and X6_D2 (long-distance) have a significant effect. This means that there is a difference in participation between those 
who live in the medium category and those who live in the far category and those who live near the category (as the basic category).

Table 5. Parameter estimation of community participation model

\begin{tabular}{lrrrrrrl}
\hline & \multicolumn{1}{c}{ B } & \multicolumn{1}{c}{ S.E. } & \multicolumn{1}{c}{ Wald } & \multicolumn{1}{c}{ df } & \multicolumn{1}{c}{ Sig. } & Odds ratio & \multicolumn{1}{c}{ Information } \\
\hline X1 & & & .441 & 2 & .802 & \multicolumn{2}{l}{ Age } \\
X1_D1 & -.210 & .713 & .087 & 1 & .768 & .811 & $25-44$ \\
X1_D2 & .190 & .785 & .059 & 1 & .808 & 1.210 & $>=45$ \\
X2 & -.443 & .600 & .546 & 1 & .460 & .642 & Gender \\
X3 & & & 5.598 & 2 & .061 & & Education \\
X3_D1 & 1.240 & .656 & 3.574 & 1 & .059 & 3.454 & Junior High School \\
X3_D2 & 1.164 & .538 & 4.678 & 1 & .031 & 3.202 & High School \\
X4 & & & 1.097 & 2 & .578 & & Main activity \\
X4_D1 & .277 & .570 & .236 & 1 & .627 & 1.319 & household matter \\
X4_D2 & -.518 & .687 & .568 & 1 & .451 & .596 & School/Other \\
X5 & & & 5.203 & 2 & .074 & & Length of stay \\
X5_D1 & 1.050 & .485 & 4.682 & 1 & .030 & 2.858 & Medium \\
X5_D2 & -.121 & .815 & .022 & 1 & .882 & .886 & Old \\
X6 & & & 5.286 & 2 & .071 & & Distance from house to a place of activity \\
X6_D1 & -1.312 & .604 & 4.719 & 1 & .030 & .269 & Medium distance \\
X6_D2 & -1.414 & .711 & 3.950 & 1 & .047 & .243 & Long distance \\
Constant & .735 & .989 & .553 & 1 & .457 & 2.086 & \\
\hline
\end{tabular}

The odds ratio value shows that those who have a house in the medium category from the place of activity have a 0.269 times (lower) probability of actively participating (medium/high category participation) than those who live in a close category. Furthermore, the odds ratio value shows that those who live in the longdistance category have a 0.243 times (lower) probability of actively participating (medium/high category participation) than those who live in the short distance category.

\section{CONCLUSIONS AND RECOMMENDATIONS}

\section{Conclusions}

The study results found that the overall level of community participation in the Kampung KB Program was moderate (average score was between 2-3). Based on the stages, community participation in the decision-making and evaluation stages is categorized as low (average score is below 2), at the implementation stage, it is categorized as a medium, and at the stage of benefit-participation is a high category (average score is above 3 ).

Furthermore, based on the analysis of the binary logit regression model, it was found that the factors that significantly influence the level of community participation are education, length of stay, and distance from house to the place of activity.

\section{Recommendations}

To make the programs in Kampung $K B$ successful, it is necessary to increase community participation at various stages of activities. Increased community participation can be done through increased socialization of the Kampung KB programs, particularly related to the stages carried out and the program's benefits for family welfare.

\section{ACKNOWLEDGMENTS}

This study's financial support was provided by a grant from the Faculty of Economics and Business, Universitas Jambi, in 2020 


\section{REFERENCES}

Afiat, M., Rahman, R., \& Elwan, L. O. M. (2018). Tingkat Partisipasi Masyarakat dalam Pelakasanaan Program Keluarga Berencana (KB) di Desa Maligano Kecamatan Maligano Kabupatan Muna. Rez Publica, 4(2), 2-20. http://ojs.uho.ac.id/index.php/rezpublica/article/view/19/3023

Alhafidh, M.D. \& Sunaryo, B. (2015). Faktor-Faktor Yang Mempengaruhi Partisipasi Masyarakat Dalam Pelaksanaan Konsolidasi Lahan di Kelurahan Kramas, Semarang. Jurnal Teknik PWK, 4(4), 753-767

Ali, M., Junaidi, M., \& Hafiz, A. (2019). Implementasi Program Desa Keluarga Berencana Bagi Kesejahteraan Masyarakat Studi Kasus Geguntur Mataram. Jurnal Ulul Albab, 23(2), 95-99.

Bintang, J. M. (2017). Partisipasi Masyarakat Dalam Program Kampung Keluarga Berencana Banjar Pilan Desa Kerta Kecamatan Payangan Kabupaten Gianyar [Universitas Brawijaya]. http://repository.ub.ac.id/5627/

BKKBN. (2015). Petunjuk Teknis Kampung KB. BKKBN.

BKKBN. (2019). Capaian Terhadap Roadmap. http://kampungkb.bkkbn.go.id/tabel Budiharjo, E., \& Sujarto, D. (2009). Kota Berkelanjutan. Penerbit Alumni.

Cohen, J. and Uphoff, N. (1980) Participation's place in rural development: Seeking clarity through specificity. World Development, 8, 213-235

Herman, H. (2019). Tingkat Partisipasi Masyarakat Dalam Perencanaan Pembangunan Desa Ulidang Kecamatan Tammerodo Kabupaten Majene. Growth, Jurnal Ilmiah Ekonomi Pembangunan, 1(1), 75-98

Lokita, D. A. (2011). Dalam, Partisipasi Masyarakat (Kasus, Program Pengelolaan Sampah Responsibility, Implementasi Corporate Social Tbk, PT Indocement Tunggal Prakarsa Tbk. di Desa Gunung Sari, Kecamatan Citeureup, Kabupaten Bogor) [Institut Pertanian Bogor]. https://repository.ipb.ac.id/handle/123456789/49964

Lutpi, H. (2016). Analisis Tingkat Partisipasi Masyarakat dalam Pengembangan Pariwisata Pantai di Kecamatan Jerowaru. Jurnal Program Studi Pendidikan, $8(3), 1-10$

Mardikanto, T., \& Soebiato, P. (2013). Pemberdayaan Masyarakat dalam Perspektif Kebijakan Publik. Alfabeta.

Muliawaty, L., \& Maharto, M. (2019). Strategi Implementasi Kebijakan Tentang Program Kampung Keluarga Berencana Menuju Keluarga Sejahtera Di Kabupaten Cirebon. Decision: Jurnal Administrasi Publik, 1(2), 82. https://doi.org/10.23969/decision.v1i2.1878

Nanda, L. D., Tan, F., \& Noer, M. (2018). Tingkat Partisipasi Masyarakat Dalam Program Penyelamatan Dan Pengelolaan Lingkungan Berkelanjutan Danau Maninjau. Jurnal Kebijakan Sosial Ekonomi Kelautan Dan Perikanan, 8(2), 105115. https://doi.org/10.15578/jksekp.v8i2.7432

Rahman, H.M. \& Indrawadi, J. (2019). Implementasi Program Kampung KB dalam Meningkatkan Kesejahteraan Masyarakat di Kelurahan Gunung Pangilun Kecamatan Padang Utara Kota Padang. Journal of Civic Education, 2(4), 295301. https://doi.org/10.24036/jce.v2i4.233

Rahman, L. (2019). Kampung KB Di Jambi Capai 202 Kampung - Daerah _. https://rri.co.id/daerah/630292/kampung-kb-di-jambi-capai-202-kampung

Ramadhan, A. (2019). Sudah 14.536 Kampung KB dibentuk di seluruh Indonesia. https://bit.ly/2ILVEx5

Ristiana, A.S.. \& Pramono, R.W.D. (2020). Faktor Dominan Yang Mempengaruhi 
Partisipasi Masyarakat Dalam Pengelolaan Kawasan Minapolitan Di Desa Gondosuli. Reka Ruang, 3(2), 60 - 70

Rizal, M., \& Yulini, F. (2016). Implementasi Kebijakan Program Keluarga Berencana (KB) Di Kabupaten Kampar (Studi Kasus Partisipasi KB Pria di Kecamatan Kampar Kiri Hililr). Jom Fisip, 3(2), 1-11. https://media.neliti.com/media/publications/117596-ID-implementasi-kebijakanprogram-keluarga.pdf

Rofiq, A. (2018). Partisipasi Masyarakat dalam Keberhasilan Pengembangan Program Posyandu Lansia di Puskesmas Jagir Surabaya. Kebijakan Dan Manajemen Publik, 6(2), 1-14. http://journal.unair.ac.id/download-fullpaperskmpc953f280cefull.pdf

Saepudin, E., Damayani, N.A. \& Budiono, A. (2018). Partisipasi Masyarakat pada Program Desa Mandiri Pangan di Kabupaten Bandung. Sosiohumaniora, 20(1), 86-94

Sarah, P., \& Bukhari, B. (2018). Partisipasi Masyarakat Terhadap Program Kampung Keluarga Berencana $(\mathrm{Kb})$ (Studi Mengenai Program Gampong Madani Kencana Di Gampong Deah Raya Kecamatan Syiah Kuala Banda Aceh). Jurnal Ilmiah $\begin{array}{llll}\text { Mahasiswa } & \text { FISIP UNSIAH, }\end{array}$ http://jim.unsyiah.ac.id/FISIP/article/view/9144

Septiandari, R.D., Nurhadi, K. \& Andini, I. (2015). Faktor-Faktor Yang Mempengaruhi Tingkat Partisipasi Masyarakat Dalam Pnpm Unit Pariwisata Di Kota Surakarta (Studi Kasus Kelurahan Sondakan, Laweyan Dan Mojosongo). Arsitektura, 13(1), Sumaryadi, I. N. (2005). Perencanaan Pembangunan Daerah Otonom dan Pemberdayaan Masyarakat. Citra Utama.

Suroso, H., Hakim, A., \& Noor, I. (2014). Faktor-Faktor Yang Mempengaruhi Partisipasi Masyarakat Dalam Perencanaan Pembangunan Di Desa Banjaran Kecamatan Driyorejo Kabupaten Gresik. Wacana Journal of Social and Humanity Studies, 17(1), 7-15. https://wacana.ub.ac.id/index.php/wacana/article/view/290

Tampi, C., Bogar, W., \& Langkai, J. E. (2020). Partisipasi Masyarakat dalam Pembangunan di Desa Pinamorongan Kecamatan Tareran. Jurnal Kajian Kebijakan Dan Ilmu Administrasi Negara (JURNAL ADMINISTRO), 2(1), 51-58. http://ejournal.unima.ac.id/index.php/administro/article/view/2000

Wahyuni, Y.T. \& Manaf, A. (2016). Partisipasi Masyarakat Dan Keberlanjutan Program Gerak Bersemi Di Griya Prima Lestari Munthe Kabupaten Kutai Timur. Jurnal Pembangunan Wilayah dan Kota, 12(4), 472-482

Widodo, F. (2018). Evaluasi partisipasi masyarakat pada pembangunan infrastruktur dalam konteks pemberdayaan masyarakat. JPM (Jurnal Pendidikan dan Pemberdayaan Masyarakat), 5(2), 108-121

Wijayanti, N. A. (2011). Tingkat Partisipasi Masyarakat Program CSR Desa Telaga dan Tingkat Kemanfaatan Program (Kasus di Karawang Internasional Industrial City). Institut Pertanian Bogor 